\title{
Soekarno Hatta Airport Social Fund Application in PT. Angkasa Pura
}

\author{
Desy Apriani" ${ }^{* 1}$, Devi Kusumawardhani ${ }^{2}$, Yazid Ma'ruf ${ }^{3}$ \\ ${ }^{1}$ Lecturer at Raharja University, ${ }^{2}$ Student Graduates at Raharja University, ${ }^{3}$ Student at Raharja \\ University \\ E-mail: ${ }^{* 1}$ desy@ raharja.info, ${ }^{2}$ devi.kusumawardhani@ @aharja.info, ${ }^{3}$ yazid@ raharja.info
}

\begin{abstract}
The development of technology is currently growing rapidly so that many attract the attention of the wider community. The development of computers is constantly dynamic and requires information that is fast, precise and systematic and does not require a long time. Therefore, the processing of social funds plays a very important role in the financial process in the company. Social funds are gifts in the form of money provided or collected with the aim of helping the social needs of the company. Processing social funds still uses Ms. Excel is running less than the maximum due to input and expense input errors so that the report is out of sync. Therefore, there needs to be a social fund processing system to manage these funds to be synchronous. The research method used consisted of data collection methods, namely observation, interviews and literature study. For analysis using the PIECES analysis method. This system uses the PHP programming language and MySQL database. The system design uses the design of the UML (Unified Modeling Language) model. The testing method used is the Blackbox Testing method. The results obtained from this study are a social fund processing application system that helps companies in terms of fund management.
\end{abstract}

Keywords — Processing, Funds, Social

\section{INTRODUCTION}

As the most important element of information technology in running a business, a computerized system is supporting the success of a business. With a computerized system all types of work can be done quickly and precisely, especially in a large and advanced company. All company activities are inseparable from the computerized system, starting from social funds where the company is required to pay contributions every month, therefore financial statements are indeed very much needed, so that must be done with computers.

PT Angkasa Pura II is currently one of the BUMNs that are engaged in Airport Services and Air Traffic Services serving the western part of Indonesia, which is currently focusing on improving the quality of services in the field of airport services and services air traffic for the sake of giving satisfaction to customers and the aviation community in general.

PT Angkasa Pura II has 13 branch offices that manage 13 airports in the western part of Indonesia, where each airport has an Airport Rescue and Fire Fighting (ARFF) unit as one of the requirements for the establishment of an airport by the Civil Aviation Organization World (International Civil Aviation Organization / ICAO) as well as one of aviation safety support systems. 
In the activity of social funds in the form of data collection or fund entry and expenditure of funds, it requires a computer to facilitate the organization of data that enters and exits. With the use of computers in an activity of each agency or company, everyone is required to be able to interact with computers or in other words be able to operate it.

With the existing problems, researchers found that the financial system of social funds for ARFF owned by PT Angkasa Pura II (Persero) has yet to be computerized (manually), in recording or data collection there are errors in the form of fund duplication, fund validity in the form of recording, and so forth.

Based on the background that has been explained, this study was conducted so that the problems described above can be resolved, so in writing the thesis the researcher took the title "SOEKARNO HATTA AIRPORT SOCIAL FUND APPLICATION IN PT. ANGKASA PURA".

\section{RESEARCH METHOD}

To obtain data in this study, several methods were used as follows:

\section{A. Method of Collecting Data}

Data collection methods used in the study consisted of the following steps:

1) Observation Method

Researchers directly make observations by making observations or direct observations of the system used, so that problems can be seen.

2) Interview Method

A method in which the researcher obtains data and information about the data of a matter by means of interviews or questions and answers with related parties to obtain more complete and clear information on the social funding system applied.

3) Library Study Methods

This research was conducted to obtain additional data by studying all the books relating to the issues discussed in the report that the author is currently studying. In this method used and applied theories from reference books, the internet and so on.

\section{B. Analysis Method}

In this information system analysis method, researchers use PIECES analysis (Performance, Information, Economic, Control, Efficiency, Service), because PIECES analysis is the basis for obtaining more specific issues regarding performance, information, economy, control, efficiency and services owned by social funds at ARFF at PT Angkasa Pura II. Researchers analyze the running system procedures and describe them using tools such as UML (Unified Modeling Language) that is done using visual paradigm software.

\section{Design Method}

In the analysis of information systems design methods for analyzing procedures that run researchers using tools (tools) in the form of UML (Unified Modeling Language) created using visual paradigm software that is based on graphics or images, visualizing, specifying, 
building, and documenting a software development system based on Object Orientied Programming through stages: Use Case Diagrams, Activity Diagrams, and Sequence Diagrams.

\section{Testing Method}

In this study the testing method used is Blackbox Testing, Blackbox Testing is a trial method that focuses on the functional requirements of the software because the blackbox trial can enable development in software to create a set of input conditions or test data that will test the functional and output of a program.

\section{E. Literature Review}

In successful research it is necessary to conduct a literature study (Literature Review), which is answered by five national journals and five international journals, namely:

1) Research in an International Journal of Civil Engineering and Technology (IJCIET) conducted by Mohd Rilizam Bin Rosli, Hussin Bin Salamon and Miftachul Huda (2018) from the University of Technology Malaysia, entitled "Distribution Management Of Zakat Fund: Recommended Proposal For Asnaf Riqab In Malaysia".

This study aims to examine the appropriate method of zakat distribution applied in Malaysia, especially in the Johor Islamic Religious Council to the ar-riqab group which is one of the eight recipients (recipients) who are entitled to receive zakat. This lesson identifies in detail the groups which can be classified as asnaf riqah as outlined by the scholar. The dates obtained from officers in the Social Welfare Department were analyzed qualitatively to identify criteria for asnaf riqab in the context of current realities. The findings show that there are groups that meet the requirements to be categorized as asnaf ar-riqah who are victims of neglect of the elderly, victims of child abuse, children involved with victims of crime and domestic violence.

2) Research in an International Journal of Economics and Finance conducted by MingChuan Chen, Chen-Fu Lee and Chien-Ming Huang (2016) from Tamkang University, entitled "The Effects of Corporate Social Responsibility on Equity Fund Returns: Evidence from China".

This study aims to investigate whether a fund management company in China has a corporate social responsibility (CSR) and its correlation with fund performance. The sample is equity funds between 2004 and 2012. The basis for the assessment for CSR is a comprehensive Chinese fund company assessment report, published by the Morningstar Chinese Research Center on January 25, 2013. This study uses a quantitative regression model with three factors to measure the fund management of companies with high ratings or The average refund rating is low and provides investors with some basis for investment decisions. The empirical results show that fund management companies with high ratings have better returns than those with low ratings. Through quantile regression estimation, it is found that market factors and refunds have a significant correlation with high ratings.

3) Research in a SI AK e-Journal conducted by Ni Luh Nik Parelawati, Nyoman Trisna Herawati and I Gusti Ayu Purnamawati (2017) from Ganesha Education University, 
entitled "Reviewing LPD Profit Contrubution in Supporting Village Development Funds and Social Funds Based on Tri Hita Karana in LPD of Jimbaran Traditional Village ".

This study aims to determine the implementation of profit contributions from the LPD for village development funds and social funds in Jimbaran Adat Village and to determine the implementation of Tri Hita Karana in channeling village development funds and social funds in Jataran Adat Village The research method used is a qualitative research method, which uses ethnographic studies and descriptive analysis methods with a qualitative approach. The type of data used in this study is primary data by means of triangulation techniques and secondary data by conducting library research.

4) Research in a journal URECOL Malang, 21 November 2018 conducted by Ramadhan Rizky Pura, Sekarsukma Syifadhiya, Sekar Aji Widyastiti and Zulfikar Bagus Pambuko (2018) entitled "The Efficiency of Sharia Banking in Indonesia in Managing Social Funds".

This study aims to analyze the level of efficiency of social funds in Islamic banks. Data analysis used the Data Envelopment Analysis technique on 8 BUS in 20132017 with an oriented output oriented VRS approach. The input variable is the receipt of zakat funds and benevolent funds, while the output variable is the use of zakat funds and benevolent funds.

5) Research in a JESI journal conducted by, Sekarsukma Syifadhiya, Sekar Aji Widyastiti and Zulfikar Bagus Pambuko (2018) entitled "Analysis of Sharia Banking Productivity in Indonesia in Managing Social Funds".

This study aims to analyze the level of productivity of social funds in Islamic banks. Data analysis used the Malmquist Productivity Index (MPI) technique on 8 BUS in 2013-2017. The input variable is the receipt of zakat funds and benevolent funds, while the output variable is the use of zakat funds and benevolent funds. The results of this study found that 5 BUS had managed social funds efficiently and 3 other BUS experienced inefficiency conditions.

This study aims to examine the Development of Human Resources (HR) in small and medium enterprises (SMEs) funded by the European Social Fund (ESF) in Poland between 2007 and 2013. This research is based on a theory that supports specific HR investments in SMEs, and uses Human Capital Theory (HCT) with several extensions. The research methodology involved a series of computer-assisted telephone interviews (CATI) in a sample of 44 SMEs who received EU funding for HRD. This also included a personal computerassisted (CAPI) interview with experts at the ESF, participant observation and analysis of project documentation. The findings indicate that ESF efforts on an international scope have a positive impact on Polish SMEs.

\section{RESEARCH RESULTS AND DISCUSSION}

\section{1) PIECES Method Analysis}

Stages of analysis of a system or application are carried out before the design stage is carried out. The purpose of implementing an analysis of a system is to find out the reason why the system is needed, formulate the requirements of the system to help plan the scheduling of the formation of the system, minimize the problems that may be contained in the system so 
that the functions contained in the system work optimally. One method of analysis used by researchers is to use PIECES, namely:

A. Performance

Performance Analysis is the ability to complete business tasks quickly so that goals can be achieved immediately. Performance is measured by the amount of production (throughput) and response time (response time) of a system.

Table 3.1 Results of Performance Analysis

\begin{tabular}{|c|l|}
\hline Parameter & \multicolumn{1}{|c|}{ Analysis Result } \\
\hline Throughput & $\begin{array}{l}\text { Input data that is not yet effective and efficient, there is an } \\
\text { error when data collection of members is not considered. }\end{array}$ \\
\hline Response Time & It takes a long time when submitting funds request reports. \\
\hline
\end{tabular}

\section{B. Information}

Information is the most important commodity for an end user in a system of decision making. With a good information system it will produce useful information as a support in responding to problems and opportunities that exist. Information is measured accurately, relevant and timely from a system.

Table 3.2 Results of Information Analysis

\begin{tabular}{|c|l|}
\hline Parameter & \multicolumn{1}{c|}{ Analysis Result } \\
\hline Accurate & $\begin{array}{l}\text { In the process of recording data often found errors, such as } \\
\text { calculation errors on social fund transactions, as a result the } \\
\text { information submitted to the treasurer is still inaccurate. }\end{array}$ \\
\hline Relevant & $\begin{array}{l}\text { lack of data presentation so that a system that is easy and can } \\
\text { provide clear information is needed. }\end{array}$ \\
\hline On Time & $\begin{array}{l}\text { When submitting social fund data reports often there is a time } \\
\text { delay, so there are obstacles when making decisions. }\end{array}$ \\
\hline
\end{tabular}

\section{Economy}

In the current system it still requires a cost, in terms of its economics the current system still costs a lot every time it will record asset data, so the current system is still less economical. Economics is measured by the cost of a system.

Table 3.3 Results of Economic Analysis

\begin{tabular}{|c|l|}
\hline Parameter & \multicolumn{1}{c|}{ Analysis Result } \\
\hline Cost & $\begin{array}{l}\text { Economic costs are still incurred, labor and time in checking } \\
\text { and recording data members for submitting funds for making } \\
\text { records on the file in the map. }\end{array}$ \\
\hline
\end{tabular}




\section{Control}

Control in the system is very necessary, which is used to improve system performance, prevent or detect misuse or system errors and to ensure the security of data and information. Control is measured by the control of the system of a system.

Table 3.4 Results of Control Analysis

\begin{tabular}{|c|l|}
\hline Parameter & \multicolumn{1}{c|}{ Analysis Result } \\
\hline System Control & $\begin{array}{l}\text { Fill in the data of members in the system control and fund } \\
\text { submission that is still using the fund request form so that it is } \\
\text { still less effective. }\end{array}$
\end{tabular}

\section{E. Efficiency}

Control in the system is very necessary, which is used to improve system performance, prevent or detect misuse or system errors and to ensure the security of data and information. Control is measured by the control of the system of a system.

Table 3.5 Efficiency Analysis Results

\begin{tabular}{|c|l|}
\hline Parameter & \multicolumn{1}{c|}{ Analysis Result } \\
\hline Source of Cost of Funds & The paper used for recording data and files is too much. \\
\hline Source of energy funds & $\begin{array}{l}\text { One of the staff does the work that enters the system, while a } \\
\text { lot of member data has to be inputted, as well as reports that } \\
\text { have been waiting too long. Therefore it greatly slows down } \\
\text { the work. }\end{array}$ \\
\hline
\end{tabular}

F. Service

The services provided are vry supportive in improving quality. Service Is a factor that determines whether the institution can achieve the objectives of policy formation or not. Because development is triggered by good service satisfaction. Service is measured by the service process of a system.

Table 3.6 Results of Analysis Services

\begin{tabular}{|c|l|}
\hline Parameter & \multicolumn{1}{c|}{ Analysis Result } \\
\hline \multirow{3}{*}{ Service Process } & $\begin{array}{l}\text { The service process provided by staff to members is still lacking. } \\
\text { Because the current system does not facilitate staff, which results } \\
\text { in frequent errors in the data collection of fund submission } \\
\text { members. }\end{array}$ \\
\hline
\end{tabular}


2) Display of Fund Processing Applications on PT. Angkasa Pura

A. Display Login Page

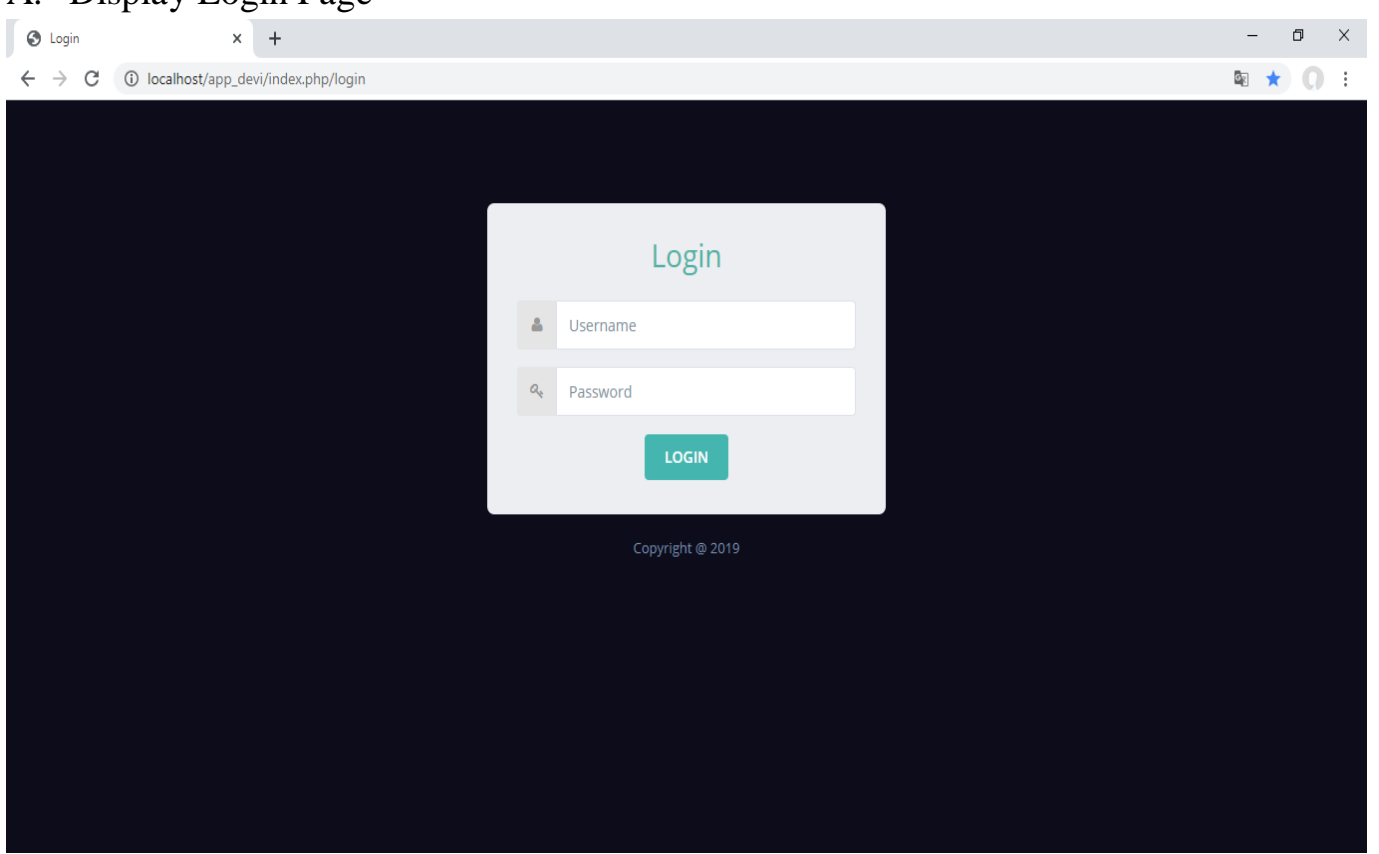

Picture 1. Display Login Page

The above display is the initial display before entering the system, each user must $\log$ in first by entering the correct username and password in order to enter the system.

B. Display Dashboard Page

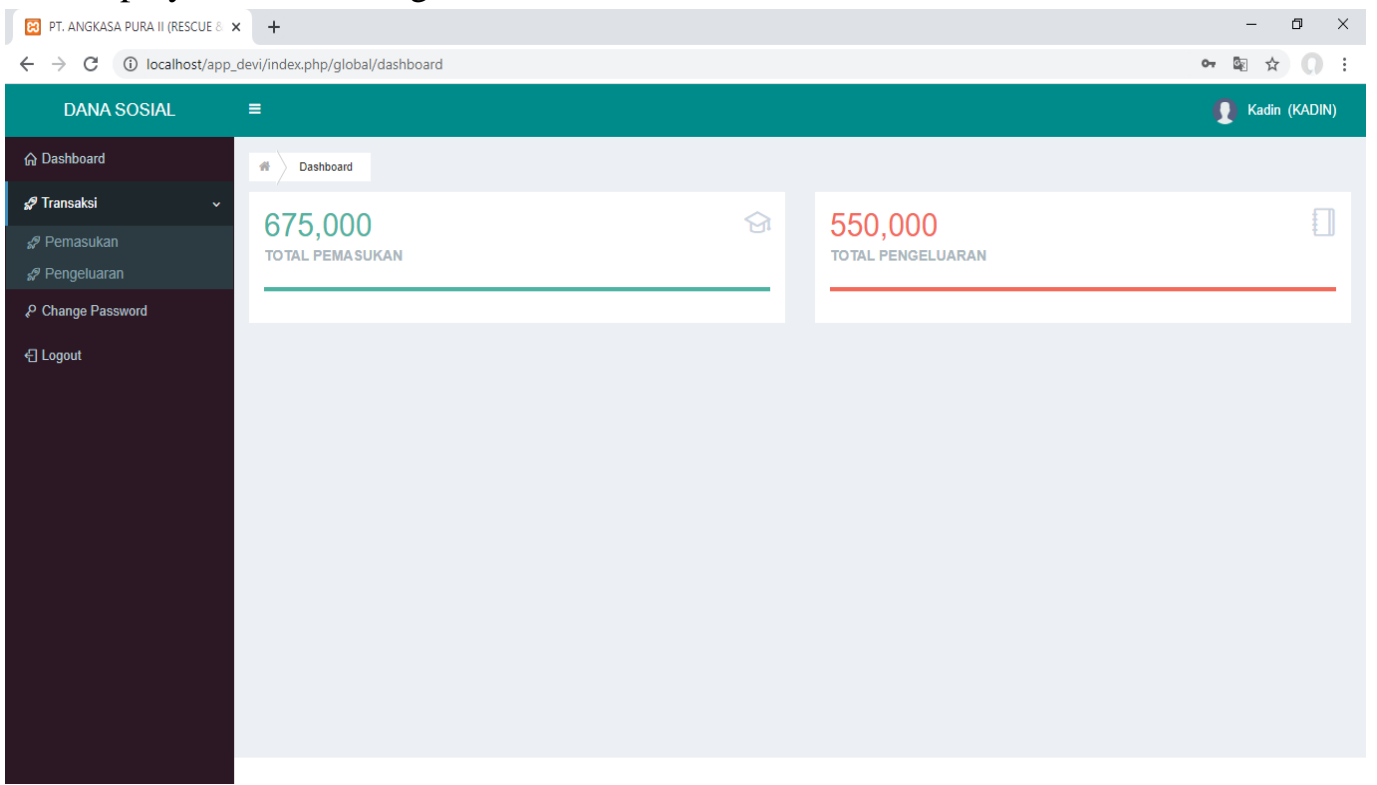

Picture 2. Display Dashboard Page

After the user has logged in correctly, a dashboard will appear in which the total revenue and total expenditure will appear. 
C. Display Input Data Income Page

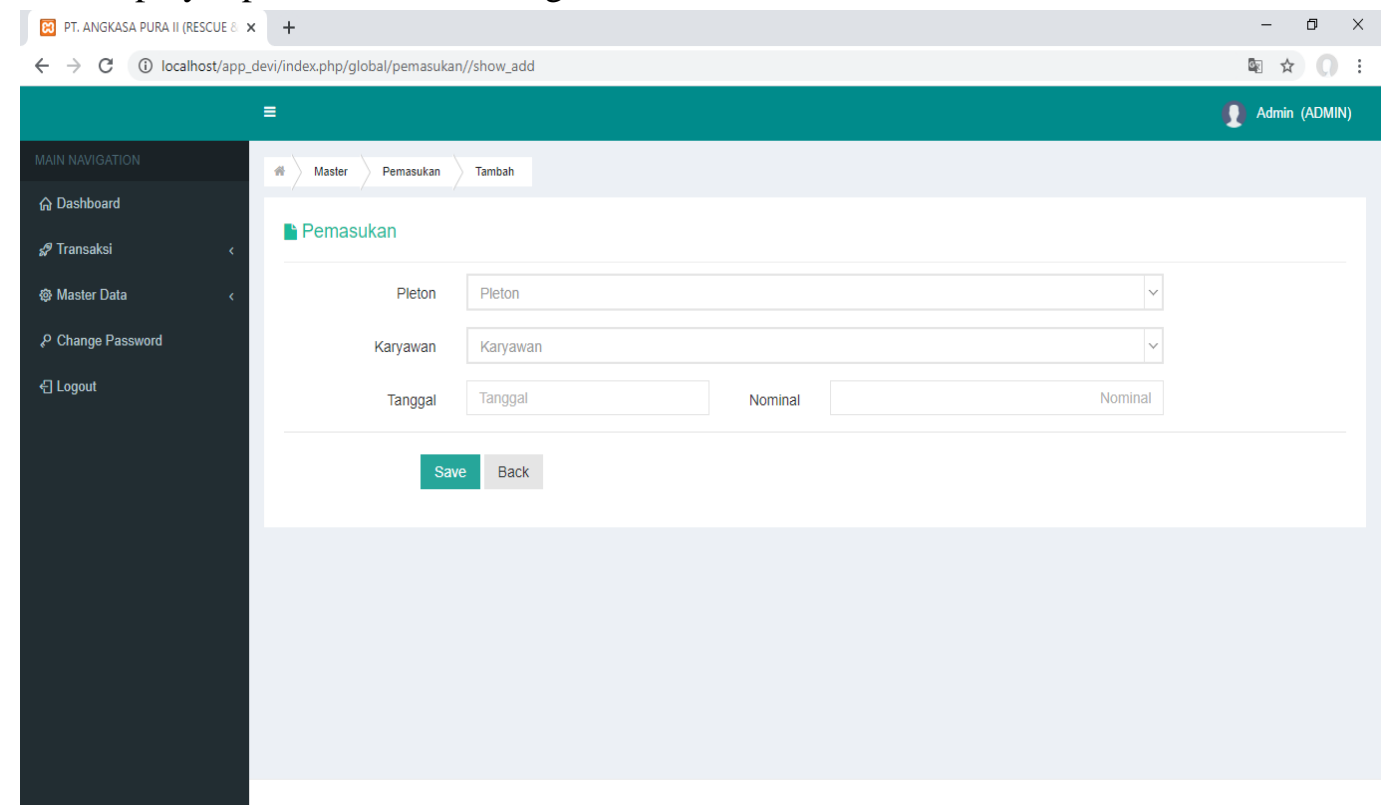

Picture 3. Display Input Data Income Page

The above display is a display form for input data input where users can fill platoons, employees, dates and nominal. Furthermore, if all data is filled, it will be stored.

D. Display Input Income Menu Page

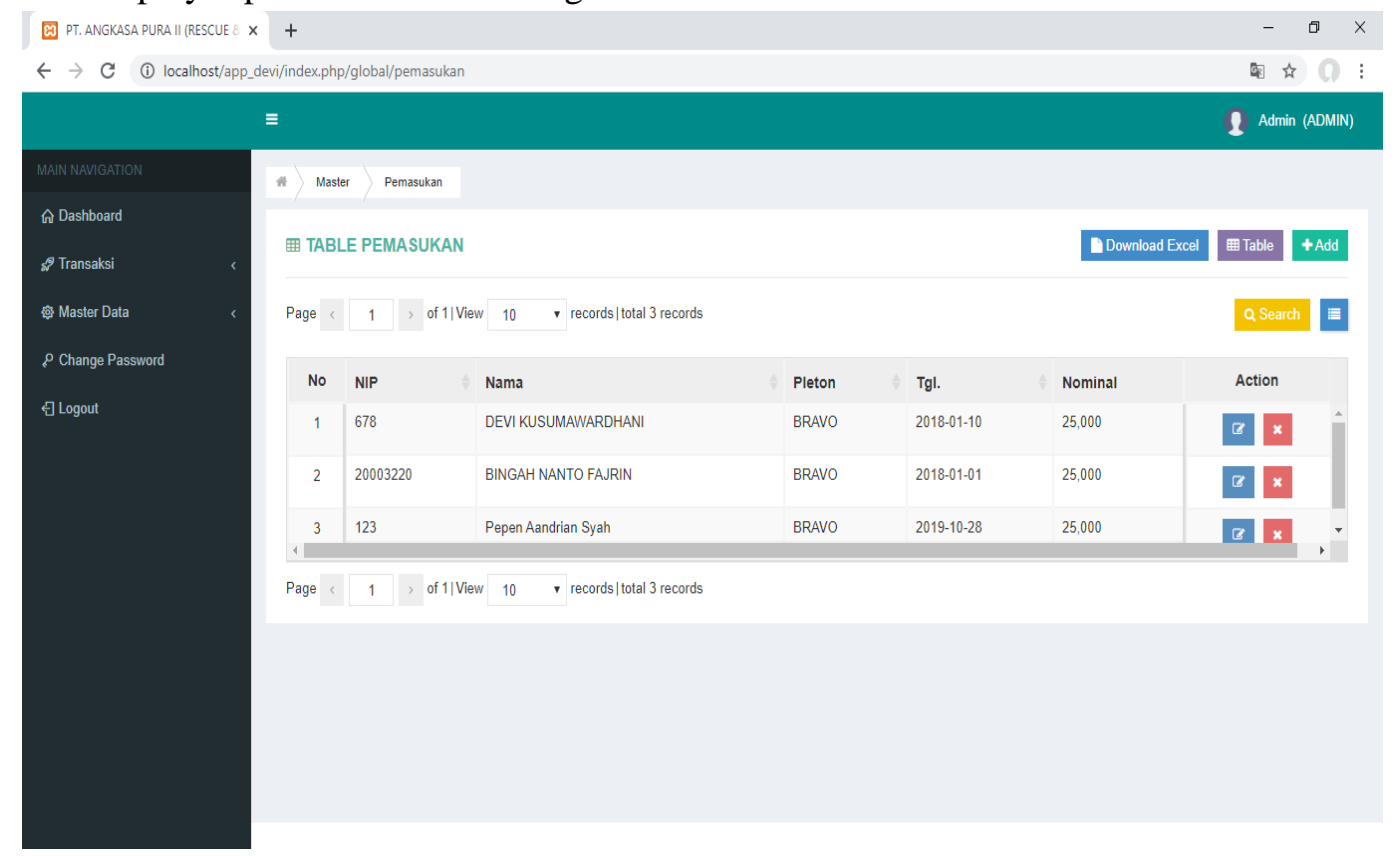

Picture 4. Display Input Income Menu Page

The above display is a view of the input menu page which presents a page in which there is data that has been inputted with input data. On this page, users can add data, edit data, delete data, search data and download data. 
E. Display Expenditure Data Input Page

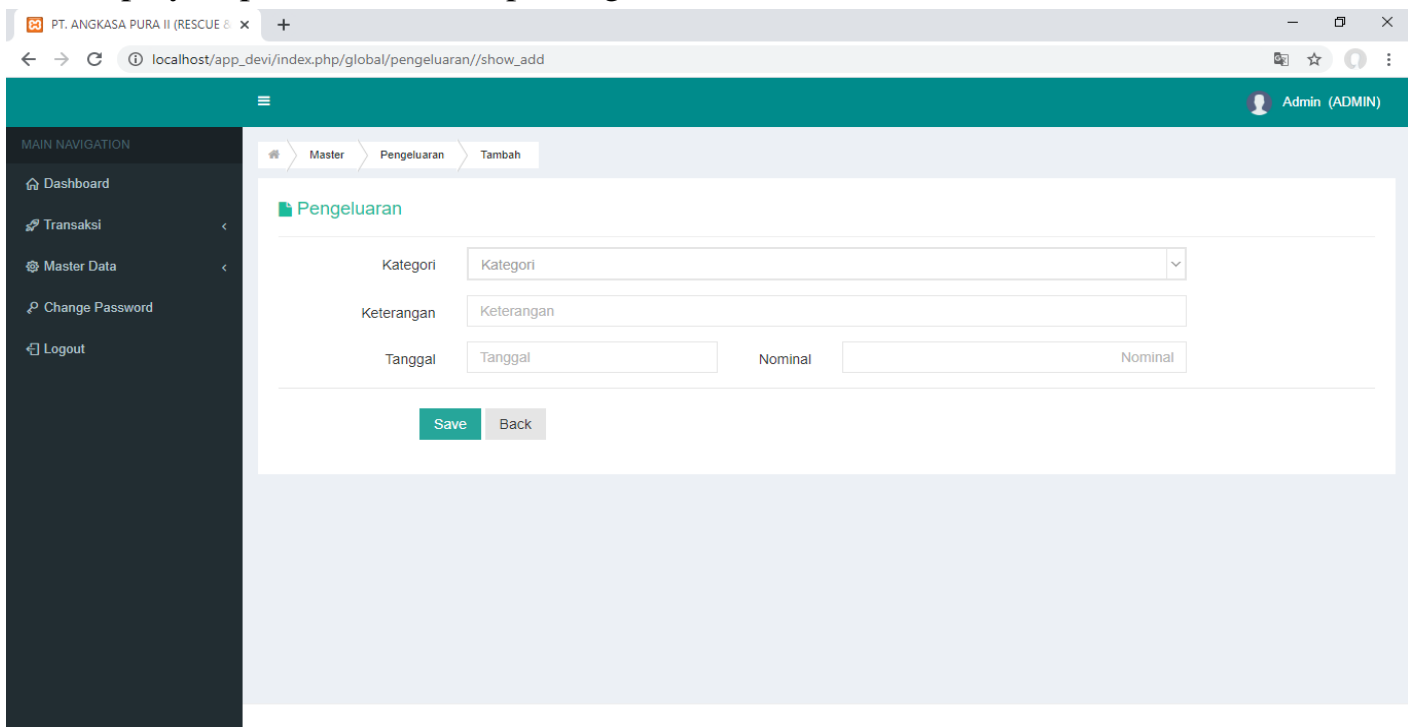

Picture 5. Display Expenditure Data Input Page

The above display is a form display for input expenditure data where the user can fill in categories, information, dates and nominal. Furthermore, if all data is filled, it will be stored.

\section{F. Display Expenditure Menu Page}

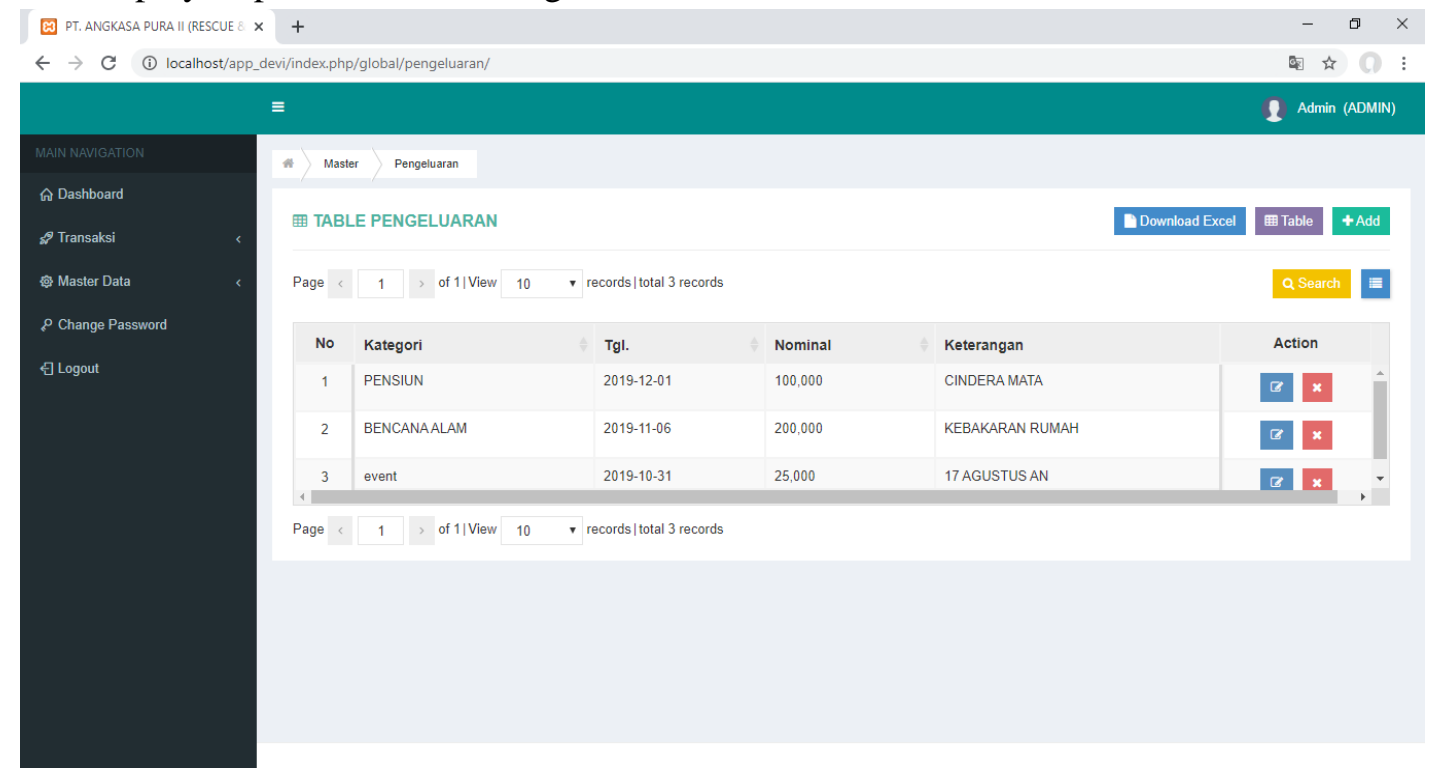

Picture 6. Display Expenditure Menu Page

The above display is a view of the expenditure menu page which presents a page in which there is data that has been inputted expenditure data. On this page, users can add data, edit data, delete data, search data and download data. 
G. Display Data Input Category Page

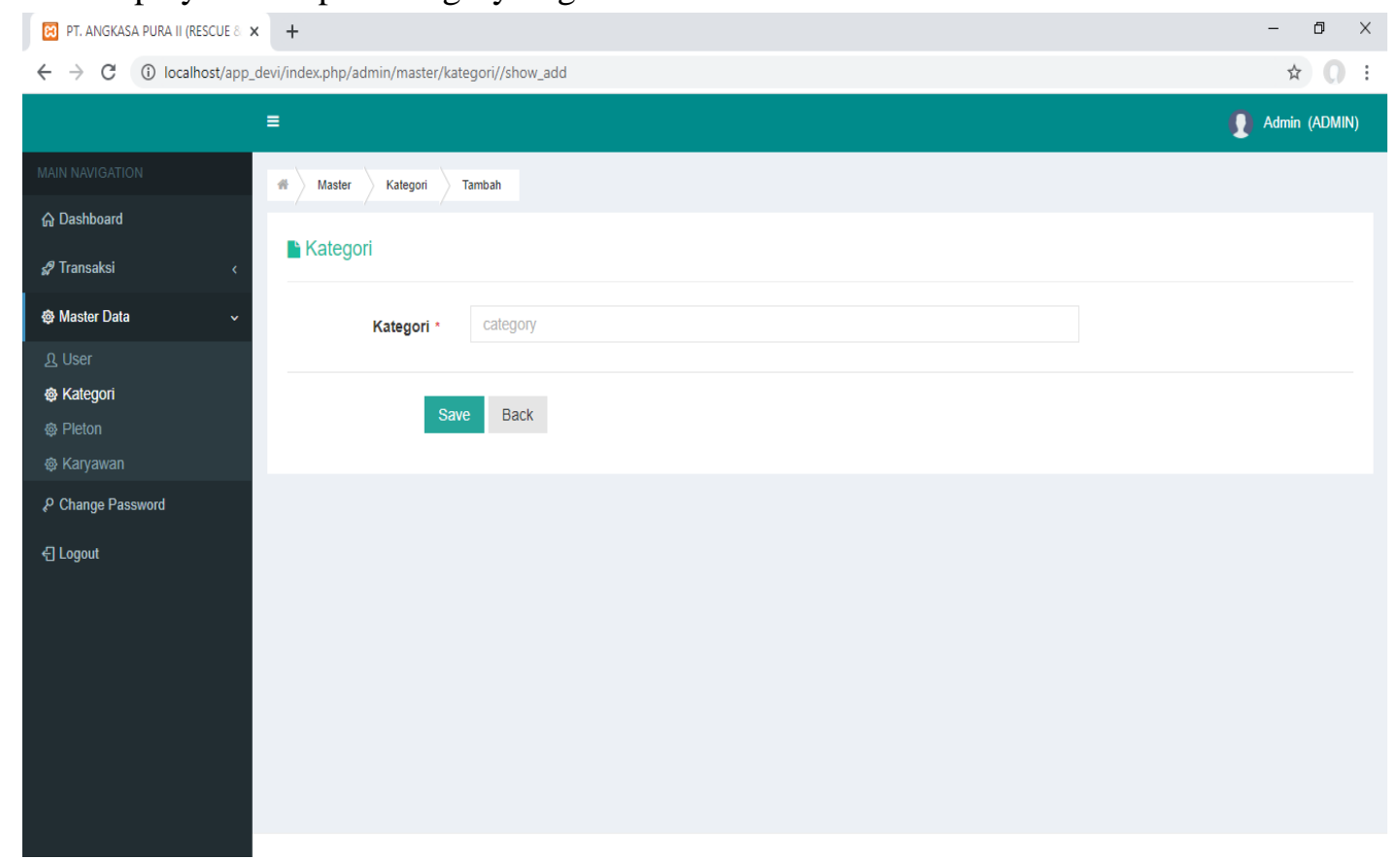

Picture 7. Display Data Input Category Page

The above display is a display for input categories where users can fill in categories. Furthermore, if the data has been filled, it will be stored.

H. Display Category Menu Page



Picture 8. Display Category Menu Page

The above display is a view of the category menu page. On this page, users can add data, edit data, delete data and search data. 
I. Display Platoon Data Input

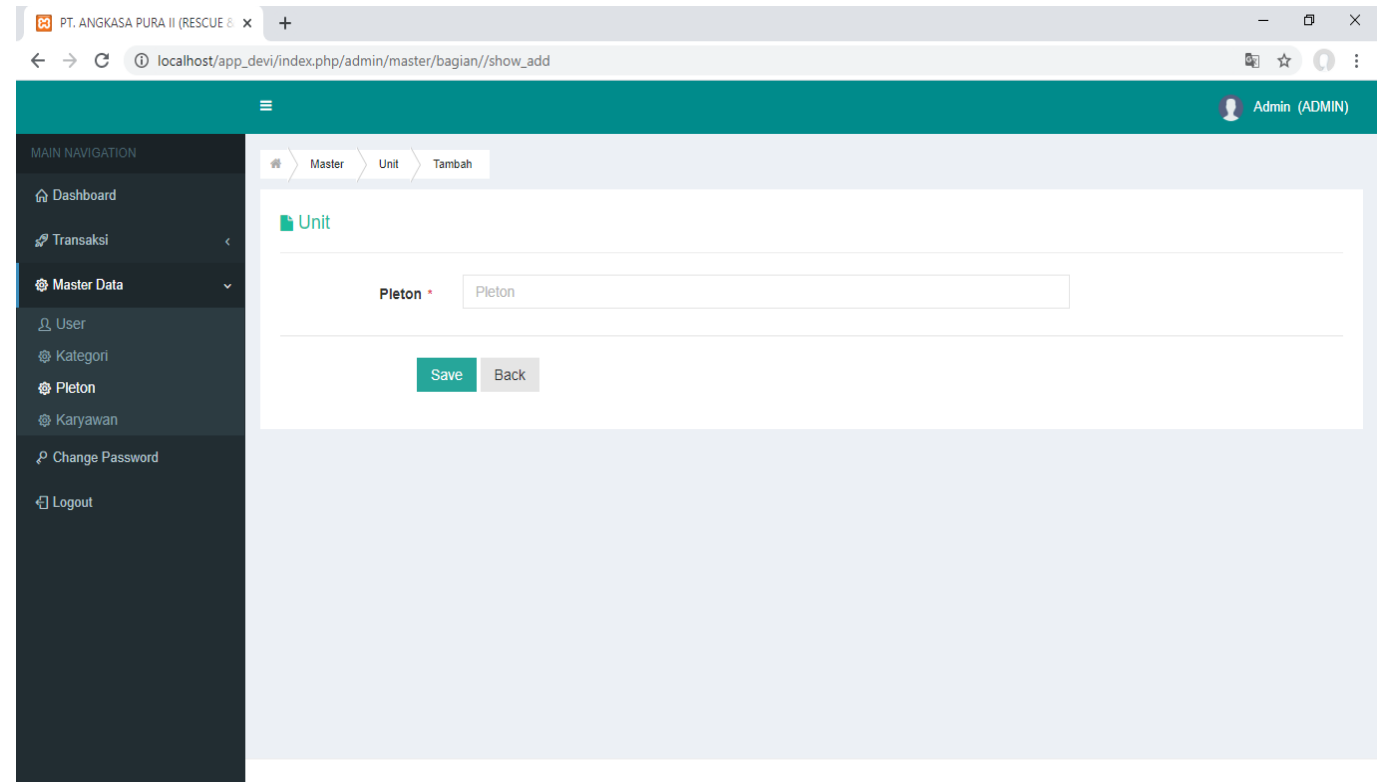

Picture 9. Display Platoon Data Input

The above display is a display for platoon input which the user can fill in the platoon. Furthermore, if the data has been filled, it will be stored.

J. Display Platoon Menu Page

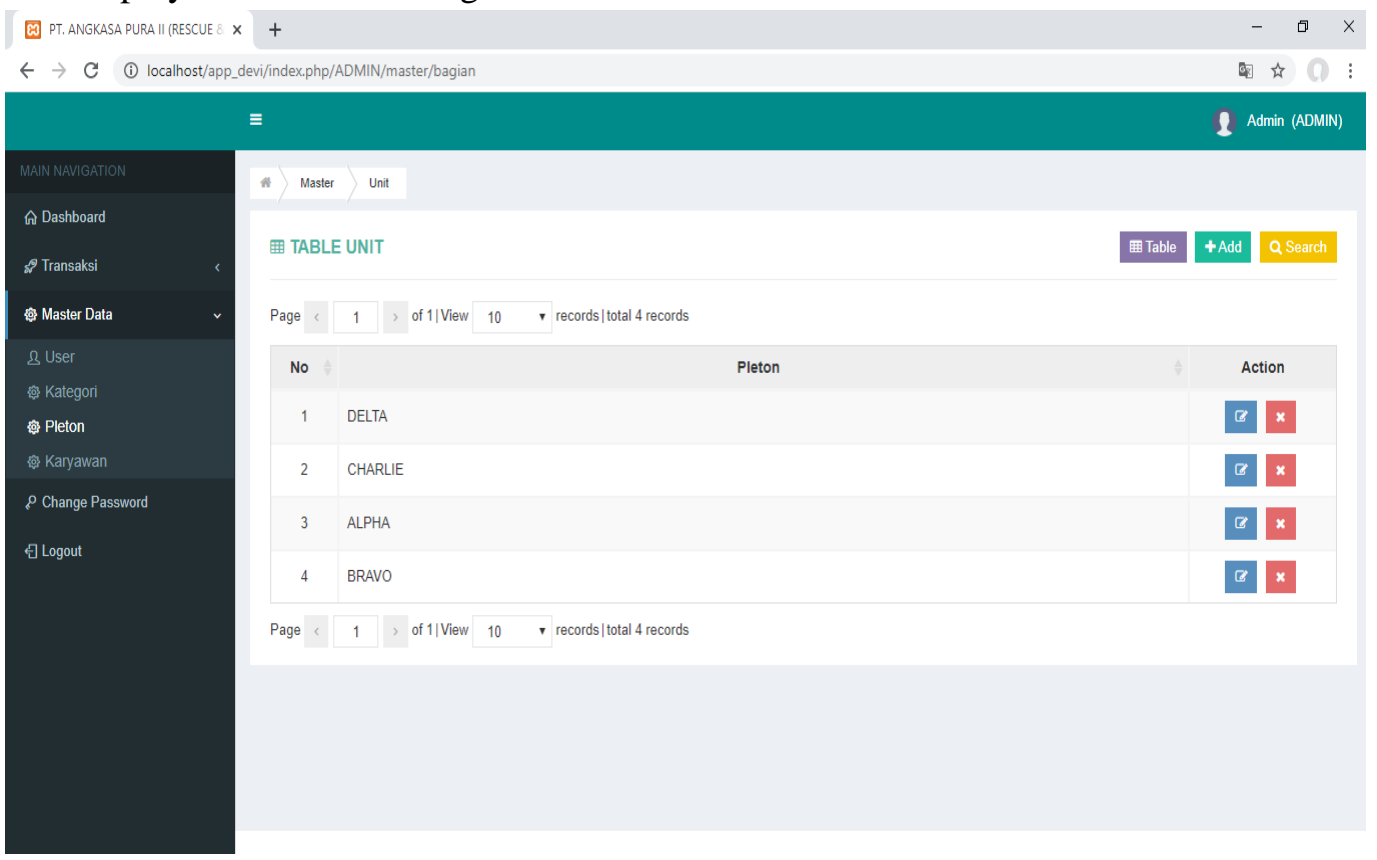

Picture 10. Platoon Menu Page

The above display is a view of the platoon menu page. On this page, users can add data, edit data, delete data and search data. 
K. Display Employee Data Input Page

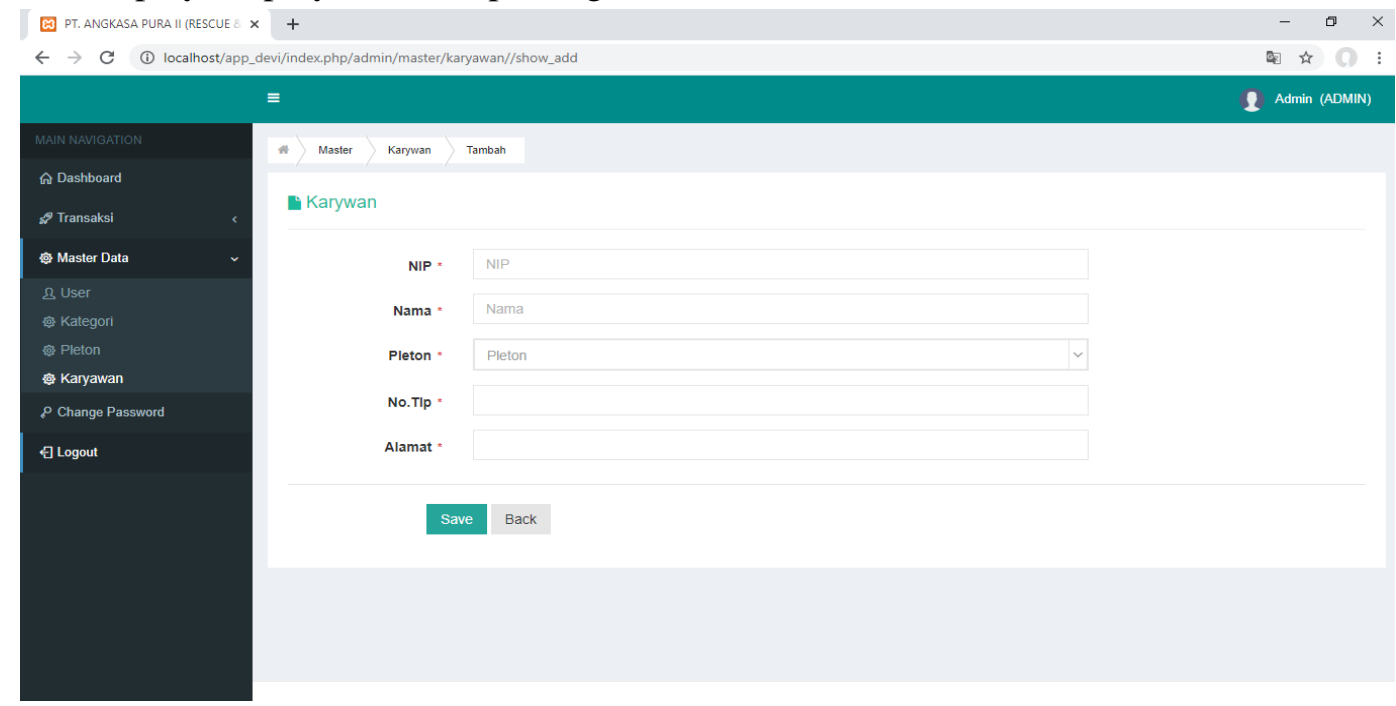

Picture 11. Display Employee Data Input Page

The above display is a display for employee input where the user can fill in the nip, name, platoon, phone number and address. Furthermore, if the data has been filled, it will be stored.

L. Display Employee Menu Page

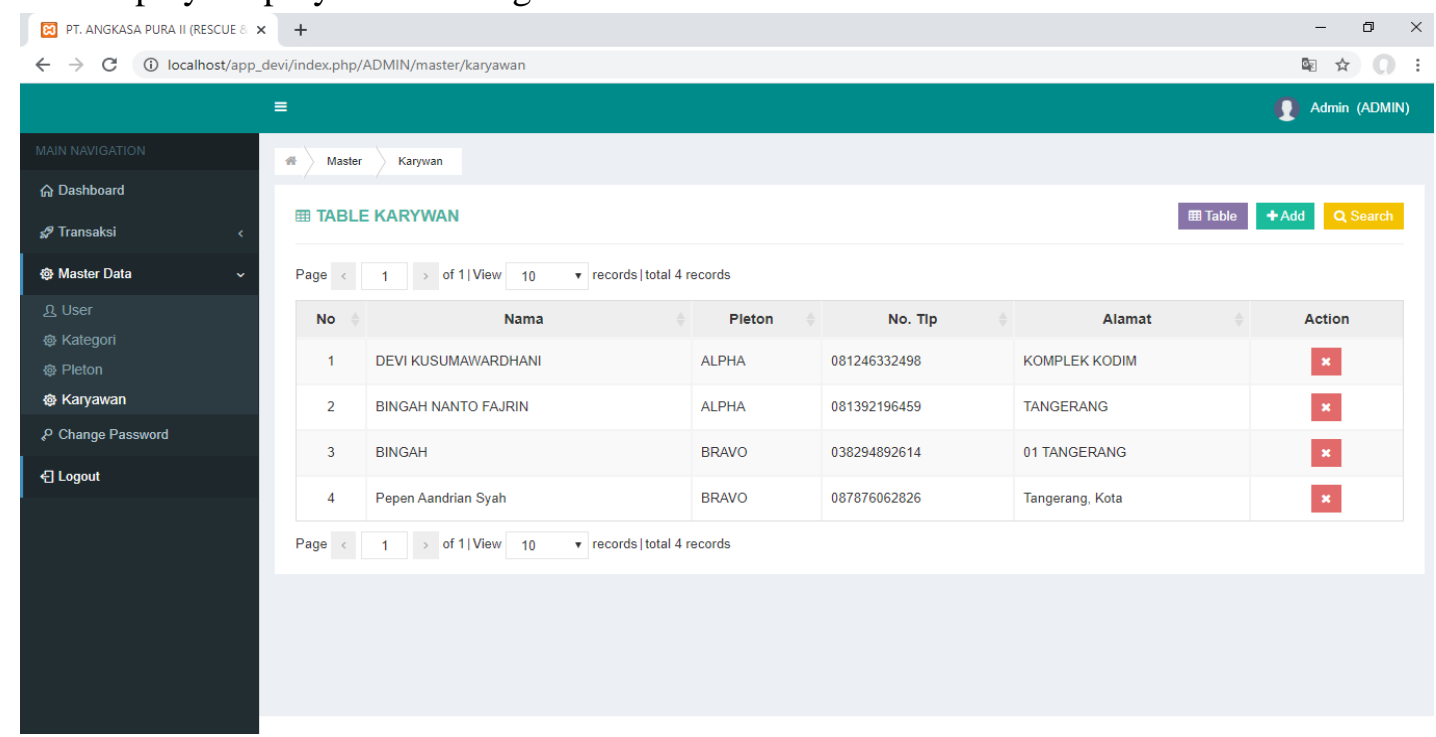

Picture 12. Display Employee Menu Page

The above display is a view of the employee menu page. On this page, users can add data, delete data and search data. 


\section{CONCLUSION}

Based on the results of research conducted at Airport Rescue and Fire Fighting, the following conclusions can be drawn:

1) The current social funding system at ARFF is still less than optimal, recording is still manual using paper and then inputted into Microsoft Excel.

2) Constraints and problems faced in the process of recording social funds that are running at this time is the recording of funds that spend a long time between income and expenditure is done using Microsoft Excel so that errors often occur in calculations and very often duplicate data.

With a web-based social funding system data - data can be stored properly in a database thereby reducing the occurrence of data - data that is lost and duplicate. Implementing a social funds information system using the PHP programming

\section{SUGGESTED}

There are several things that need to be considered so that they can be further developed, including:

1) Training is required for users to operate the system being built, so that in doing a job there are no obstacles that can result in less than optimal system performance.

2) Data backup is required on a regular basis, because if there is damage or loss of data there is still other data stored.

3) After it can be implemented properly, it is necessary to evaluate regularly so that the development of a new system can be carried out, so that deficiencies in this system can be fixed and continue to develop in accordance with increasingly rapid technological developments.

\section{REFERENCES}

[1] Rosli, M. R. B., Salamon, H. B., \& Huda, M. (2018). Distribution management of zakat fund: recommended proposal for Asnaf Riqab in Malaysia. International Journal of Civil Engineering and Technology, 9(3), 56-64.

[2] Chen, M. C., Lee, C. F., \& Huang, C. M. (2016). The effects of corporate social responsibility on equity fund returns: Evidence from China. Int. J. Econ. Financ, 8, 92.

[3] Parelawati, N. L. N., Herawati, N. T., AK, S., \& Purnamawati, I. G. A. (2017). * Mengulas kontribusi laba LPD dalam menunjang dana pembangunan desa dan dana sosial berlandaskan Tri Hita Karana di LPD Desa Adat Jimbaran. JIMAT (Jurnal Ilmiah Mahasiswa Akuntansi) Undiksha, 7(1).

[4] Putra, R. R., Syifadhiya, S., Widyastiti, S. A., \& Pambuko, Z. B. (2019). Efisiensi Perbankan Syariah di Indonesia dalam Mengelola Dana Sosial. Proceeding of The URECOL, 163-166.

[5] Putra, R. R., Syifadhiya, S., Widyastiti, S. A., \& Pambuko, Z. B. (2018). Analisis Produktivitas Perbankan Syariah di Indonesia dalam Mengelola Dana Sosial. JESI (Jurnal Ekonomi Syariah Indonesia), 8(1), 74-80. 